\title{
Cadmium Accumulation and Its Histological Effect on Brain and Skeletal Muscle of Zebrafish
}

\author{
Abeer Ghazie Azize Al-sawafi ${ }^{1,2 \dagger}$, Lixiao Wang ${ }^{1 \dagger}$ and Yunjun Yan ${ }^{1 *}$ \\ ${ }^{1}$ Key Laboratory of Molecular Biophysics of the Ministry of Education, College of Life Science and Technology, Huazhong University of Science \\ and Technology, Wuhan 430074, China \\ ${ }^{2}$ Environmental and Pollution Engineering Department, Foundation of Technical Education, Technical College, Basrah, Iraq \\ ${ }^{\dagger}$ These authors contributed equally to this work
}

${ }^{*}$ Corresponding author: Yan Y, Key Laboratory of Molecular Biophysics of the Ministry of Education, College of Life Science and Technology, Huazhong University of Science and Technology, Wuhan 430074, China, Tel: +86-27-87792213; E-mail: yanyunjun@hust.edu.cn

Received date: May 1, 2017; Accepted date: May 18, 2017; Published date: May 25, 2017

Copyright: (c) 2017 Al-sawafi AGA, et al. This is an open-access article distributed under the terms of the Creative Commons Attribution License, which permits unrestricted use, distribution, and reproduction in any medium, provided the original author and source are credited.

Citation: Al-sawafi AGA, Wang L, Yan Y. et al. Cadmium Accumulation and Its Histological Effect on Brain and Skeletal Muscle of Zebrafish. J Heavy Met Toxicity Dis. 2017, 2:1.

\section{Abstract}

Acute toxicity of cadmium (Cd) to zebrafish (Danio rerio) was studied. The 24, 48, 72 and $96 \mathrm{~h}$ LC50 values (with $95 \%$ confidence limits) estimated by probit analysis were $16.73 \quad(20.03-13.98), \quad 12.88 \quad(14.96-11.08), \quad 11.46$ (13.21-9.94), $9.68(11.12-8.43) \mathrm{mg} \mathrm{L}^{-1}$, respectively. To determine the accumulation and cyto-toxicity of $\mathrm{Cd}$ on the brain and skeletal muscle of zebrafish, specimens of zebrafish were exposed to three concentrations of cadmium (0.65 mg Cd L-1, C1; $0.97 \mathrm{mg} \mathrm{Cd} \mathrm{L}^{-1}, \mathrm{C} 2$; and 1.94 $\mathrm{mg} \mathrm{Cd} \mathrm{L^{-1 }}, \mathrm{C} 3$ (corresponding to $1 / 15$ th, $1 / 10$ th and $1 / 5$ th of $96 \mathrm{~h} \mathrm{LC50)}$, respectively for 25 days. The concentration of $\mathrm{Cd}$ in the fish tissue was detected by Inductively Coupled Plasma Mass Spectrometer (ICP-MS). Tissue alterations of brain and skeletal muscle were observed under light microscope. Cadmium concentrations of the treated fishes showed a significantly exponential increase over time and peaked at Day 25. In term of histomorphology of brain and skeletal muscle, obvious tissue chaos was noticed in the treated fishes compared to the control group. This mess clearly appeared at Day 25 at $\mathrm{C} 3$ in the brain where the tissue showed different extents of granule cell loss, degeneration of Purkinje cells, aggregation area of gliosis and many areas of necrosis. Ultra-structural damage of moderate or low levels was observed in the fishes at $\mathrm{C} 1$ and $\mathrm{C} 3$ after 5 days and $\mathrm{C} 1$ after 25 days of treatment. In the skeletal muscle at 25 days of C3 treatment, different degrees of swelling and high necrosis were observed. This indicates that a defense mechanism was started with the accumulation of metal $\mathrm{Cd}$ in the tissues over time. Thus, the information provided in this study may be very useful for the deep understanding of the mechanisms of $\mathrm{Cd}$ stress in fish.
Keywords: Cadmium; Zebrafish; LC50; Bioaccumulation; Histopathology

\section{Introduction}

Cadmium (Cd), a common aquatic environmental contaminant, is associated with wide variety of human activities and products like pigments, ceramics, plastics, glasses, vehicle tires and other synthetics [1]. The dispersion of $\mathrm{Cd}$ in the environment has increased over the past decades because of its extensive industrial uses such as nickel-cadmium battery production and metal plating $[1,2]$. For example, it can enter the water environment from industrial operations, chemically agricultural manuring and mining activities $[3,4]$. It is a highly toxic heavy metal and recognized as one of the most harmful metal contaminants [5]. Cd is a biologically nonnecessary, non-biodegradable and persistent heavy metal, thus, it has high toxic possibilities for human and animals' health $[3,6]$.

Moreover, continuous exposure to low level of $\mathrm{Cd}$ may have a gross biological effect comparable to that of frequent exposures of more intensity. Field studies have demonstrated various degrees of pollution to aquatic systems via direct or indirect $\mathrm{Cd}$ inputs [4]. Generally, in freshwater fish, $\mathrm{Cd}$ absorption is carried out through three ways, namely, through gills, skin and from food via the intestinal wall [7]. Considerable quantity of $\mathrm{Cd}$ will be accumulated in various tissues of fishes in aquatic environment, and it is based on style of exposure, diet or waterborne. Yet accumulation of $\mathrm{Cd}$ in fish muscle was rarely reported though it can pose severe impact on fish without any visible signs $[8,9]$. Because of bio magnification of $\mathrm{Cd}$ in food chain, when consumed by human, it will become a more important subject for aquatic science [10]. As pointed out by Fraser et al. [11], fish and seafood, a part of healthy diet, all bio accumulates heavy metals. In particular, the bioaccumulation of $\mathrm{Cd}$ and other minerals in food chain is causing worries as they can have harmful impacts 
on human and animal health, and sometimes can cause Alzheimer's and Parkinson's diseases [12]. Usually, fish and seafood are one of the key links between heavy metals in the environment and human exposure.

Biomarkers are actions of sub-organismal replies in organisms or exposed bio systems which can prove exposure to, or the impacts of, environmental pollutants. During last two decades, the science of biomarkers has greatly advanced. Histo-cytological responses are relatively easy to identify, and can potentially be relevant to health and fitness of individuals which, in turn, allows further extrapolation to population/ community impacts. A wide variety of histo-cytological modifications in fish have been developed and recommended as biomarkers for monitoring the impacts of contamination [13]. Cd exposure may also cause some patho-physiological harm.

In this context, the present investigation was designed to study the pattern of bioaccumulation of $\mathrm{Cd}$ in tissues of zebrafish exposed to sub lethal concentrations of $\mathrm{Cd}$, as well as examining the toxicity of $\mathrm{Cd}$ on the fish and histo-pathological responses in brain and skeletal muscle of zebrafish served as primary indicator of exposure to pollutants, especially heavy metals.

\section{Materials and Methods}

\section{Animals and acute toxicity testing}

Zebrafish (Danio rerio) samples were purchased from the Institute of hydrobiology, Chinese academy of Science, Wuhan, P. R. China, with the body weight from 0.295 to $0.847 \mathrm{~g}$ and length of about $3.1-4.6 \mathrm{~cm}$. The fishes were acclimatized to the laboratory conditions in glass aquaria filled with $4 \mathrm{~L}$ of dechlorinated water. Each aquaria contained ten fishes, which were randomly exposed to a range of concentrations of $\mathrm{Cd}(0$, 1, 5, 10, 20, $30 \mathrm{mg} \mathrm{L}^{-1}$ ) diluted in water. Cd-free water was used as control. Each test concentration was replicated 3 times. All exposures were conducted at $25-28^{\circ} \mathrm{C}$ with a $12: 12 \mathrm{~h}$ light: dark photoperiod. The exposure solution was always aerated and $50 \%$ of the contaminated water was changed every $48 \mathrm{~h}$ for the duration of the exposure period. The water quality parameters ( $\mathrm{pH}$ and temperature) were measured daily. During the acute toxicity experiment, fish were not fed and mortality of the fish due to exposure was recorded up to $96 \mathrm{~h}$ at every $24 \mathrm{~h}$ interval to obtain LC50 values of Cd, following the probity analysis method described by Finney [14].

\section{Bio concentration test}

Bioaccumulation of $\mathrm{Cd}$ in zebrafish was examined by exposing 400 fish to sub lethal concentrations of $\mathrm{Cd}$ in 4 different aquaria. Each aquarium contained $40 \mathrm{~L}$ of tap water and 100 zebrafish. Control group were kept in uncontaminated water for $\mathrm{Cd}$ bioaccumulation levels and histology analysis. In tank C1, fish were exposed to low contaminated water (at a nominal $\mathrm{Cd}$ concentration of 1/15th of the LC50 value, 0.645 $\mathrm{mg} \mathrm{L}^{-1}$ ). In tank $\mathrm{C} 2$, fish were exposed to mid contaminated water (at a nominal $\mathrm{Cd}$ concentration of $1 / 10$ th of the LC50 value, $0.968 \mathrm{mg} \mathrm{L}^{-1}$ ). In the remaining unit (C3) fish were exposed to highly contaminated water (at a nominal $\mathrm{Cd}$ concentration of $1 / 5$ th of the LC50 value, $\left.1.936 \mathrm{mg} \mathrm{L}^{-1}\right)$. Then record the $\mathrm{Cd}$ values over 0,15 and 25 days. They were fed twice a day with artificial dry food, after the remainder food was removed; further, one third of the contaminated water was changed every $24 \mathrm{~h}$ during the exposure period. The fish were dissected at the end of each exposure period. Then the $\mathrm{Cd}$ concentration in the water and entire zebrafish was measured according to the procedure described by Cambier et al. [2]. $1 \mathrm{~g}$ wet weight of fish tissue was digested with $3 \mathrm{ml}$ of nitric acid $\left(65 \% \mathrm{HNO}_{3}\right)$ in a pressurized medium (borosilicate glass tubes) at $100^{\circ} \mathrm{C}$ for $3 \mathrm{~h}$ and then diluted with $20 \mathrm{ml}$ of deionized water before $\mathrm{Cd}$ concentration was measured. Water samples were taken from the aquaria at 0,15 and 25 days to determine the amounts of $\mathrm{Cd}$ inside. The $10 \mathrm{ml}$ of water was filtrated and $200 \mu$ l of concentrated nitric acid $(65 \%$ $\mathrm{HNO}_{3}$ ) was added. Thus, $\mathrm{Cd}$ concentrations of water and tissue samples were measured by Inductively Coupled Plasma Mass Spectrometer (ICP-MS) in Faculty of Material and Chemistry, China University of Geosciences, Wuhan, P. R. China.

\section{Histopathological changes analysis}

For histological examination, tissues (brain and skeletal muscle) were fixed in paraformaldehyde, dehydrated through a graded series of ethanol, cleared in xylene and embedded in paraffin. Sections of $7 \mu \mathrm{m}$ thickness were prepared from paraffin blocks using a rotary microtome and then stained with haematoxylin-eosin. Histopathological changes were examined under a Nikon Eclipse Bio microscope. Histological alterations were scored as: (-), no histopathology; (+), histopathology in $<20 \%$ of the fields; $(++)$, histopathology in $20-60 \%$ of the fields; and (+++) histopathology in all fields.

\section{Statistical analysis}

Computations were performed using graph pad program and results were given as mean. For all statistical results, a probability of $\mathrm{p}<0.05$ was considered significant. The median Lethal Concentration (LC50) values and 95\% confidence limits of $\mathrm{Cd}$ to zebrafish during different periods were calculated by probit analysis. The Bio Concentration Factor (BCF) of $\mathrm{Cd}$ in zebrafish was estimated using the following equation: $\mathrm{BCF}=\mathrm{Cf} / \mathrm{Cw}$, where $\mathrm{Cf}$ is the concentration of $\mathrm{Cd}$ in the fish and $\mathrm{CW}$ is the concentration of $\mathrm{Cd}$ in the exposure solution.

\section{Results}

\section{Median lethal concentration and behavior variations}

None of the fishes died during the course of the experiment. The control fish swam normally without any mark of abnormality. After 15 days of exposure to $\mathrm{Cd}$, the fishes showed erratic swimming and aggressive. In addition, hyperventilation was especially evident in fishes and excess mucus occurred on their opercular surface at 25 days of $\mathrm{Cd}$ exposure. The LC50-96 $\mathrm{h}$ for $\mathrm{Cd}$ on zebrafish was found to be 
$9.68 \mathrm{mg} \mathrm{L}^{-1}$, with a range (95\% confidence limits) of $11.12-8.43$ $\mathrm{mg} \mathrm{L}^{-1}$.

Table 1 presents the mortality and the LC10, LC50, and LC90 for $\mathrm{Cd}$ experimentally found at different periods and varying concentrations of Cd. No mortality was however observed in the control group during the experimental period. As well, The
$96 \mathrm{~h}$ LC50 concentration is less than those of $24 \mathrm{~h}, 48 \mathrm{~h}$ and 72 $h$, which shows that the more the duration period is, the less the concentration is required. Thus with the increase of exposure time, LC50 values decreased from $16.73 \mathrm{mg} \mathrm{L}^{-1}(24 \mathrm{~h})$ to $12.88 \mathrm{mg} \mathrm{L}^{-1}(48 \mathrm{~h})$ to $11.456 \mathrm{mg} \mathrm{L}^{-1}(72 \mathrm{~h})$ then to $9.68 \mathrm{mg}$ $\mathrm{L}^{-1}(96 \mathrm{~h})$ in Cd (Table 1).

Table 1: Mortality percentage and LC10, LC50, and LC90 values of Zebrafish at different exposure times and varying concentrations of $\mathrm{Cd}$.

\begin{tabular}{|c|c|c|c|c|c|c|c|c|}
\hline \multirow{2}{*}{$\begin{array}{l}\text { Concentration } \\
\left(\mathrm{mg} \mathrm{L}^{-1}\right)\end{array}$} & \multicolumn{2}{|l|}{$24 \mathrm{~h}$} & \multicolumn{2}{|l|}{$48 \mathrm{~h}$} & \multicolumn{2}{|l|}{$72 \mathrm{~h}$} & \multicolumn{2}{|l|}{$96 \mathrm{~h}$} \\
\hline & $\begin{array}{l}\text { Dead } \\
\text { fish/ } \\
\text { total fish }\end{array}$ & $\begin{array}{l}\text { Mortality } \\
(\%)\end{array}$ & $\begin{array}{l}\text { Dead } \\
\text { fish/ } \\
\text { total } \\
\text { fish }\end{array}$ & $\begin{array}{l}\text { Mortality } \\
(\%)\end{array}$ & $\begin{array}{l}\text { Dead } \\
\text { fish/ } \\
\text { total } \\
\text { fish }\end{array}$ & $\begin{array}{l}\text { Mortality } \\
(\%)\end{array}$ & $\begin{array}{l}\text { Dead } \\
\text { fish/ } \\
\text { total fish }\end{array}$ & $\begin{array}{l}\text { Mortality } \\
(\%)\end{array}$ \\
\hline Control & $0 / 30$ & 0 & $0 / 30$ & 0 & $0 / 30$ & 0 & $0 / 30$ & 0 \\
\hline 1 & $0 / 30$ & 0 & $0 / 30$ & 0 & $0 / 30$ & 0 & $0 / 30$ & 0 \\
\hline 5 & Mar-30 & 10 & Oct-30 & 36.6 & Oct-30 & 36.6 & $13 / 30$ & 49.99 \\
\hline 10 & Jul-30 & 23.33 & Nov-30 & 26.6 & Nov-30 & 26.6 & $14 / 30$ & 53 \\
\hline 20 & $15 / 30$ & 50 & $24 / 30$ & 80 & $25 / 30$ & 83.33 & $25 / 30$ & 83.33 \\
\hline 30 & $24 / 30$ & 80 & $30 / 30$ & 86.6 & $30 / 30$ & 96.6 & 100 & 100 \\
\hline LC10 & \multicolumn{2}{|c|}{$7.89(9.12-6.83)$} & \multicolumn{2}{|c|}{$6.43(7.56-5.47)$} & \multicolumn{2}{|c|}{$5.96(7.08-5.025)$} & \multicolumn{2}{|c|}{$5.24(6.34-4.34)$} \\
\hline LC50 & \multicolumn{2}{|c|}{$16.73(20.03-13.98)$} & \multicolumn{2}{|c|}{$12.88(14.96-11.08)$} & \multicolumn{2}{|c|}{$11.46(13.21-9.94)$} & \multicolumn{2}{|c|}{$9.68(11.12-8.43)$} \\
\hline LC90 & \multicolumn{2}{|c|}{$35.47(49.63-25.36)$} & \multicolumn{2}{|c|}{$25.79(33.48-19.87)$} & \multicolumn{2}{|c|}{$22.01(27.62-17.54)$} & \multicolumn{2}{|c|}{$17.87(21.60-14.78)$} \\
\hline \multirow{2}{*}{ Regression line } & \multicolumn{2}{|c|}{$y=3.92 x+0.20$} & \multicolumn{2}{|c|}{$y=4.24 x+0.29$} & \multicolumn{2}{|c|}{$y=4.51 x+0.22$} & \multicolumn{2}{|c|}{$y=4.81 x+0.26$} \\
\hline & $\mathrm{R}^{2}=0.9745$ & $R^{2}=0.9507$ & & $R^{2}=0.9657$ & & $R^{2}=0.9654$ & & \\
\hline
\end{tabular}

\section{Cd bioaccumulation in fish tissues}

Cd concentrations identified in the water and entire zebrafish after different period of exposure showed significant differences among all treatments $(P<0.01$, Table 2$)$. Therefore, a progressive increase of $\mathrm{Cd}$ accumulation in fish were noticed when shifting from the control exposure to the 15 and 25 days exposures, for all treatments, which reached a high level after 25 days. The computed accumulation factors in whole fish body were $14.3,18.16$ and 13.48 in C1, C2 and C3, respectively.

Unlike this projected accumulation pattern, a recession of Cd accumulation in fish body in $\mathrm{C} 3$ were observed when shifting from 15 to 25 days exposures. So, the $\mathrm{Cd}$ concentration in the treated fish appeared to increase exponentially and culminate at Day 25 , which was 95.33, 66.04 and $24.42 \mu \mathrm{g} \mathrm{Cd} \cdot \mathrm{g}^{-1}$ wet weight.

While the concentration of $\mathrm{Cd}$ in the water was maintained at a constant level, as the exposure solution was fully renewed every $24 \mathrm{~h}$, and it was detected by (ICP-MS) during different periods (Table 2 ).
Table 2: Bio concentration factor (BCF) of $\mathrm{Cd}$ in zebrafish exposed to $\mathrm{C} 1, \mathrm{C} 2$ and $\mathrm{C} 3$ for 0,15 and 25 days.

\begin{tabular}{|c|c|c|c|c|c|c|c|c|c|}
\hline \multirow{2}{*}{$\begin{array}{l}\text { Time } \\
\text { (day) }\end{array}$} & \multicolumn{3}{|l|}{ C1 } & \multicolumn{3}{|l|}{ C2 } & \multicolumn{3}{|l|}{ C3 } \\
\hline & Cf & Cw & BCF & Cf & Cw & BCF & Cf & Cw & BCF \\
\hline 0 & 3.2 & 0.15 & 0.48 & 1.74 & 0.28 & 0.48 & 1.38 & 0.52 & 0.72 \\
\hline 15 & 12.57 & 0.14 & 1.76 & 18.92 & 0.22 & 5.24 & 24.25 & 0.52 & 12.66 \\
\hline 25 & 95.33 & 0.15 & 14.3 & 66.04 & 0.27 & 18.16 & 24.42 & 0.55 & 13.48 \\
\hline
\end{tabular}

\section{Histopathological variations}

The general histological screening indicated a low to high incidence of chemical damage on tissues of zebrafish after 5 and 25 days exposure to $\mathrm{Cd}$. Histopathological alterations were registered in the tissue from brain and skeletal muscle and are summarized in Table 3, shown in Figures $\mathbf{1}$ and 2 . The control 
group did not show any histological changes in any of the tissues examined. In return, the structures of the brain and skeletal muscle of Cd-treated fish were changed, the longer time of exposure, the more severe. Histopathological changes were not observed in the skeletal muscle tissue of the treated fishes in $\mathrm{C} 1$ after 5 days. As shown in Figure 1, the musculoskeletal tissues from zebrafish exposed to other dose groups were detected to be various degrees of swelling, coagulation necrosis accompanied by infiltration of hemocytes and high necrosis. Figure $\mathbf{2}$ shows the brain of zebrafish also exhibiting different degrees of granule cell loss, degeneration of Purkinje cells aggregation area of gliosis and tissue anarchy in many areas where the cells appeared well spaced due to intercellular spaces of different width.

Table 3: Histopathologic analysis of skeletal muscle and brain tissues from zebrafish exposed to $\mathrm{Cd}$ for 5 days and for 25 days.

\begin{tabular}{|l|l|l|l|l|}
\hline \multirow{2}{*}{$\begin{array}{l}\text { Histopatholog } \\
\text { y findings }\end{array}$} & \multicolumn{2}{|c|}{5 days } & \multicolumn{2}{|c|}{25 days } \\
\cline { 2 - 5 } & $\begin{array}{l}\text { Skeletal } \\
\text { Muscle }\end{array}$ & Brain & $\begin{array}{l}\text { Skeletal } \\
\text { Muscle }\end{array}$ & Brain \\
\hline 0 & - & - & - & - \\
\hline C1 & + & - & ++ & ++ \\
\hline C3 & ++ & ++ & +++ & +++ \\
\hline
\end{tabular}

(-) no histopathology; (+) histopathology in $<25 \%$ of fields; (++) histopathology in $>75 \%$ of fields; $(+++)$ histopathology in all fields

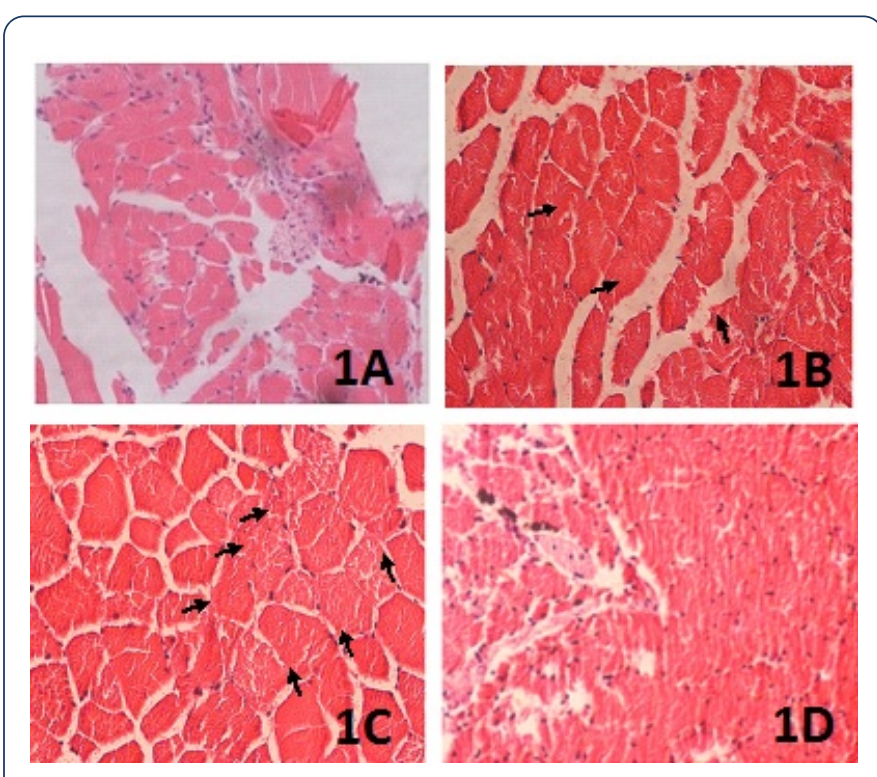

Figure: 1 Characteristic histopathological change in the skeletal muscle of zebra fish revealed by $\mathrm{H} \& \mathrm{E}$ staining (400X). (A) Control; (B) Swelling skeletal muscle fibers ( $\uparrow$ ) after exposure to $\mathrm{C} 3$ of $\mathrm{Cd}$ for 5 days; (C) Swelling and coagulation necrosis ( $\uparrow$ ) after exposure to $\mathrm{C} 1$ of $\mathrm{Cd}$ for 25 days (D) large region of coagulation necrosis accompanied by infiltration haemocytosis after exposure to $\mathrm{C} 3$ of $\mathrm{Cd}$ after 25 days.

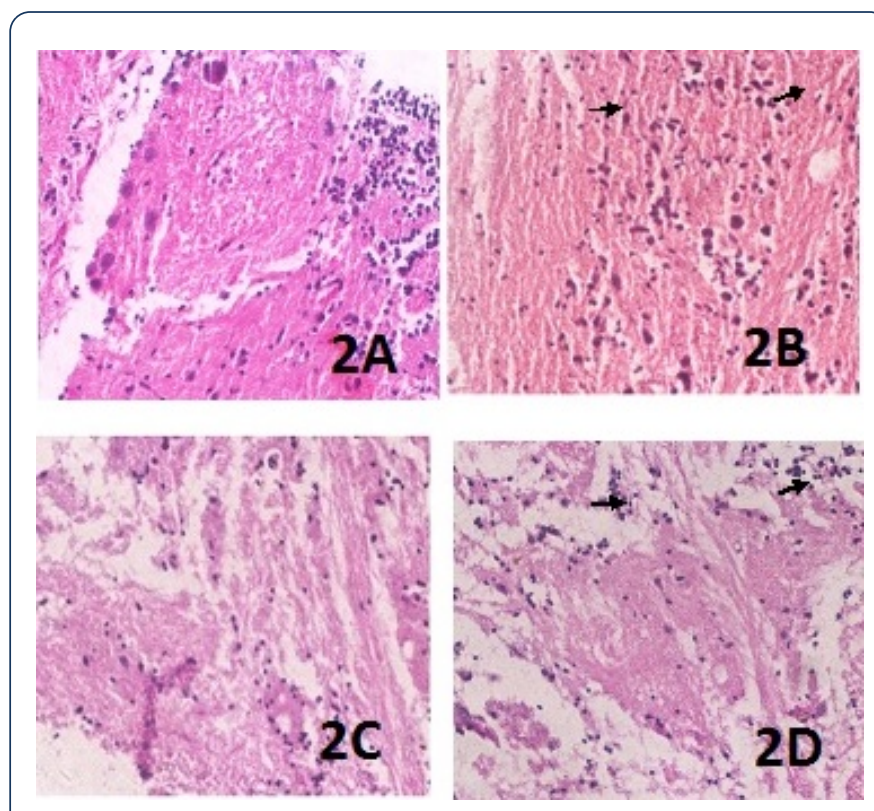

Figure: $\mathbf{2}$ Characteristic histopathological changes in the brain of zebra fish revealed by H\&E staining (400X). (A) Control; (B) degeneration of Purkinje cells and severe loss of granule cells after exposure to $\mathrm{C} 3$ of $\mathrm{Cd}$ for 5 days; (C) degeneration of Purkinje cells and neutrophil loss after exposure to $\mathrm{C} 1$ of $\mathrm{Cd}$ for 25 days (D) aggregation area of gliosis ( $\uparrow)$ and showed areas of necrosis after exposure to $\mathrm{C} 3$ of $\mathrm{Cd}$ after 25 days.

\section{Discussion}

In the present study, LC50 of Cd for zebrafish after $96 \mathrm{~h}$ exposure was $9.68 \mathrm{mg} \mathrm{L}^{-1}$. So far, $96 \mathrm{~h} \mathrm{LC50}$ of $\mathrm{Cd}$ showed considerable differences among fish species. For example, Synechogobius hasta has a $96 \mathrm{~h} \mathrm{LC50}$ of $0.79 \mathrm{mg} \mathrm{L}^{-1}$ [5]; Ophiocephalus striatus (Channa) has a $96 \mathrm{~h} \mathrm{LC50} \mathrm{of} 0.63 \mathrm{mg} \mathrm{L}^{-1}$ [15], while edible carp Catla catla has a LC50 value of $4.53 \mathrm{mg}$ $\mathrm{L}^{-1}$ [16]. These values show that $\mathrm{Cd}$ is less toxic to zebrafish than other species, similar values are found to Clarias macrocephalus $\times$ Clarias gariepinos, $13.6 \mathrm{mg} \mathrm{L}^{-1}$ (LC50-96 h) [17] and to L. rohita $22.92 \mathrm{mg} \mathrm{L}^{-1}$ [18]. However, the differences in the 24, 48, 72 and $96 \mathrm{~h}$ LC50 values between zebrafish and other fishes may be attributed to the fact that metal induced changes in physiology might differ from metal to metal, species to species, and also influenced by chemical structure of metal compound and experimental conditions (water temperature, salinity, oxygen content and $\mathrm{pH}$ ) [19].

Previous studies have evaluated the neurotoxicity of $\mathrm{Cd}$ in vitro. Unlike lead, an uncompetitive inhibitor which affected the enzyme-substrate binding affinity, $\mathrm{Cd}$ was a noncompetitive inhibitor to acetyl cholinesterase and the activity of this enzyme decreased by $50 \%$ when exposed to $\mathrm{Cd}$ of $5.7 \mathrm{mM}$ for $77 \mathrm{~min}[12,20]$. Forecasting the toxic impacts of $\mathrm{Cd}$ to fishes in natural exposure environments stays tough though many studies have examined the relationship between metal exposure, accumulation and toxicity under laboratory circumstances. Fish accumulate $\mathrm{Cd}$ in the tissues mainly 
through contaminated water and their diet [21]. Furthermore, waterborne $\mathrm{Cd}$ can be accumulated in zebrafish more efficiently than dietary $\mathrm{Cd}$. Increasing numbers of research have demonstrated several factors affecting $\mathrm{Cd}$ accumulation in fish tissues, including environmental metal concentration and time of exposure [22]. Many authors have shown that animal tissues could accumulate heavy metals in dose and time dependent manner. Fishes have the capacity to accumulate heavy metal in their tissues by gill surface and the wall of gut tract to greater levels than the environmental toxin concentration [23]. In agreement to our results, Malekpouri et al. [24] noted that the accumulation of $\mathrm{Cd}$ in muscles of common carp (Cyprious carpio) has been elevated under increased concentration and duration of $\mathrm{Cd}$ exposure, as well as the maximum accumulation was in the third treatment (i.e., $100 \mathrm{ppb}$ for dissolved cadmium) after 90 days of exposure. Kim et al. [25] also showed a similar increasing pattern of $\mathrm{Cd}$ accumulation in olive flounder muscle. Reynders et al. [26] also indicated that common carp was dependent on the time of exposure and the doses of $\mathrm{Cd}$.

The mineral accumulation that we detected is also clearly the cause of the behavioral response observed in fish after 15 days of exposure. And the change became more pronounced at 25 days, when the zebrafish showed hyperventilation in addition to erratic swimming and excess mucus were secreted on their opercular surface. Similar observation of Paralichthys olivaceus also showed erratic swimming and excessive mucus production on their opercular surface [27], as well as in Channa punctatus [28]. It has been verified that the toxicity of $\mathrm{Cd}$ was mainly attributed to the free radicals and oxidative stress produced by this metal. Typically, it can combine with the thiol group of enzymes working in antioxidant processes or occupy the place of magnesium and calcium in certain reactions and disrupt the normal functioning [29]. Finally the intoxicated organism suffered from respiratory, excretory and circulatory disorders as well as neurotoxicity [1]. Behavioral alterations have been established as sensitive indicators of chemically induced stress in aquatic organisms. Moreover, behavioral alterations like erratic swimming, restlessness and surfacing may be a kind of avoiding reaction to the heavy metal narcotic effects or to change in sensitivity of chemoreceptors [19].

Pathological changes in fish are strong indicators of exposure to environmental pressures. Histopathology has been widely used as biomarker in assessing the health of fish exposed to $\mathrm{Cd}$ both in laboratory and field, as reported by Annabi et al. [30]. Au [13] confirmed the histopathological evaluation in fish as an extremely valuable tool to determine the toxicopathic impacts of material because they may better reflect the real health state of the animal than other biomarker/diagnosis methods. Our histological results showed that zebrafish exposed to $\mathrm{Cd}$ pollution were adversely affected at the tissue level compared to control groups, while the histopathological changes in the tissues were identical to typical histological responses to the contaminants. In our study, Cd caused changes to skeletal muscle structure of the zebrafish, as evidenced by swelling and necrosis of the skeletal muscle. Ramah [21] showed that the pathological changes in the muscle tissue as swelling and necrosis of muscle fibers occurred to grass carp (Ctenopharyngodan idella) when exposed to rice herbicides butachlor $1.5 \mathrm{~kg} \mathrm{ha}^{-1}$, oxyfluorfen $0.25 \mathrm{~kg} \mathrm{ha}^{-1}$ and thiobencarb $1.5 \mathrm{~kg} \mathrm{ha}^{-1}$ for 12 days. $\mathrm{Cd}$ exposure caused serious damage to the fish brain, as evidenced by a series of lesions in the brain tissue by degeneration of Purkinje cells and necrosis, which may later affect normal physiological activities. Such changes in brain and skeletal muscle suggest that these tissues are sensitive to Cd toxicity. Similarly, Favorito et al. [31] indicated the histomorphological harm of $\mathrm{Cd}$ to zebrafish brain became clearer with increasing $\mathrm{Cd}$ accumulation in the brain. In contrast, Xing et al. [32] reported the histological examination with a low to moderate dose, incidence of chemical damage on brain and kidney tissues of common carp after a 40 days exposure to ATR, CPF and ATR/CPF combination. As an indicator of exposure to pollutants, histology represents a powerful tool to evaluate the impacts of contamination, particularly in relation to sub-lethal and chronic effects.

\section{Conclusion}

This histological investigation showed that these changes are a typical cellular response to heavy metals and may represent an important parameter for the study of environmental contaminants. Cd-accumulation in fish is affected by some parameters such as Cd-concentration and exposure time. Most of these primary factors must be taken into consideration while estimating ecotoxicological impacts of $\mathrm{Cd}$ on fish populations. Furthermore, large accumulations of $\mathrm{Cd}$ in fishes are of significant attention. Because the later consumption by human might cause some pathophysiological disturbances in human body. With regard to this, further investigation needs to be done in order to clarify accurate of fish Cd toxicity on human.

\section{Conflict of Interest}

The authors declare that there are no conflicts of interest.

\section{References}

1. Sharma B, Shweta S, Nikhat JS (2014) Biomedical implications of heavy metals induced imbalances in redox systems. BioMed Res Int.

2. Cambier S, Gonzalez P, Durrieu G, Bourdineaud JP (2010) Cadmium-induced genotoxicity in zebra fish at environmentally relevant doses. Ecotox Environ Safe 73: 312-319.

3. Zaki MS, Mostafa SO, Fawzi OM, Khafagy M, Bayumi FS (2009) Clinicopathological, biochemical and microbiological change on grey mullet exposed to cadmium chloride. American-Eurasian J Agric Environ Sci 5: 20-23.

4. Gonzalez P, Baudrimont M, Boudou A, Bourdineaud JP (2006) Comparative effects of direct cadmium contamination on gene expression in gills, liver, skeletal muscles and brain of the zebrafish (Danio rerio). Biometals 19: 225-235.

5. Liu XJ, Luo ZL, Xiong BX, H ZY, Li XD, et al. (2011) Antioxidant responses, hepatic inter mediary metabolism, histology and 
ultrastructure in Synechogobius hasta exposed to water borne cadmium. Ecotox Environ Safe 74: 1156-1163.

6. Al-Sawafi AGA, Yan Y (2013) Alterations of acetyl cholinesterase activity and antioxidant capacity of zebrafish brain and muscle exposed to sub lethal level of cadmium. Int J Environ Sci Dev 4: 327-330.

7. Jayakumar P, Vattapparumbil IP (2006) Patterns of cadmium accumulation in selected tissues of the catfish Clarias batrachus (Linn.) exposed to sublethal concentration of cadmium chloride. Vet Arh 76: 167-177.

8. Gupta A, Rai DK, Pandey RS, Sharma B (2009) Analysis of some heavy metals in the riverine sediments and fish from river Ganges at Allahabad. Environ monitor Assess 157: 449-458.

9. De Conto Cinier C, Petit-Ramel M, Faure R, Garin D, Bouvet $Y$ (1999) Kinetics of cadmium accumulation and elimination in carp Cyprinus carpio tissues. Comp Biochem Physiol C Pharmacol Toxicol Endocrinol 122: 345-352.

10. Mansour SA, Sidky MM (2002) Eco toxicological studies: 3 Heavy metals contaminating water and fish from Fayoum Governorate, Egypt. Food Chem 78: 15-22.

11. Fraser M, Surette C, Vaillancourt C (2013) Fish and seafood availability in markets in the Baie des Chaleurs region, New Brunswick, Canada: a heavy metal contamination baseline study. Environ Sci Pollut R 20: 761-770.

12. Vivek KG, Shweta S, Anju A, Nikhat JS, Sharma B (2015) Phytochemicals mediated remediation of neurotoxicity induced by heavy metals. Biochem Res Int.

13. Au DWT (2004) The application of histo-cytopathological biomarkers in marine pollution monitoring: a review. Mar Pollut Bull 48: 817-834.

14. Finney DJ (1971) Probit analysis (3rd edn.). Cambridge University Press, Cambridge, England.

15. Bais UE, Lokhande M (2012) Effect of cadmium chloride on histopathological changes in the freshwater fish Ophiocephalus striatus (channa). Int J Zool Res 8: 23-32.

16. Sobha K, Poornima A, Harini P, Veeraiah K (2007) A study on biochemical changes in the fresh water fish, (hamilton) exposed to the heavy metal toxicant cadmium chloride. Kathmandu Univ J Sci Eng Technol 3: 1-11.

17. Pantunga N, Helander KG, Helandera HF, Cheevaporna V (2008) Histopathological alterations of hybrid Walking catfish (Clarias macrocephalus $\times$ Clarias gariepinus) in acute and subacute cadmium exposure. Environ Asia pp: 22-27.

18. Latif A, Ali M, Kaoser R, Iqbal R, Umer K, et al. (2012) Effect of cadmium chloride and ascorbic acid exposure on the vital organs of freshwater Cyprinid, Labeo rohita. Afr J Biotechnol 11: 8398-8403.

19. Kaushal BT, Mishra A (2013) Investigation of acute toxicity cadmium on snakehead fish Channa puntatus-a comparative toxicity analysis on median lethal concentration. Int J Adv Biol Res 3: 289-294.
20. Vivek KG, Abhishek K, Nikhat JS, Sharma B (2016) Rat brain acetyl cholinesterase as a biomaker cadmium induced neurotoxicity. Open Access J Tox.

21. Ramah K (2011) Histopathological study on the effect of rice herbicides on grass carp (Ctenopharyngodan idella). Afr J Biotechnol 10: 1112-1116.

22. Annabi A, Said K, Messaoudi I (2013) Cadmium: Bioaccumulation, histopathology and detoxifying mechanisms in fish. Am J Res Commun 1: 60-79.

23. Chevreuil M, Carru AM, Chesterikoff A, Boet P, Tales E, et al. (1995) Contamination of fish from different areas of the river Seine (France) by organic (PCB and pesticides) and metallic (Cd, $\mathrm{Cr}, \mathrm{Cu}, \mathrm{Fe}, \mathrm{Mn}, \mathrm{Pb}$ and $\mathrm{Zn}$ ) micropollutants. Sci Total Environ 162: 31-42.

24. Malekpouri P, Moshtaghie AA, Hosseini R, Ebrahimi E (2011) Short and long-term effects of waterborne cadmium on growth and its muscle accumulation in common carp fish (Cyprinus carpio), an experimental study. Turk J Fish Aquat Sci 11: 587-593.

25. Kim SG, Jee JH, Kang JC (2004) Cadmium accumulation and elimination in tissues of juvenile olive flounder, Paralichthys olivaceus after sub-chronic cadmium exposure. Environ Pollut 127: 117-123.

26. Reynders H, Van Campenhout K, Bervoets L, De Coen WM, Blust $R$ (2006) Dynamics of cadmium accumulation and effects in common carp (Cyprinus carpio) during simultaneous exposure to water and food (Tubifex tubifex). Environ toxicol chem 25: 1558-1567.

27. Yildirim MZ, Benl A, Selv M, Ozkul A, Erkoç F, et al. (2006 ) Acute toxicity, behavioral changes, and histopathological effects of deltamethrin on tissues (gills, liver, brain, spleen, kidney, muscle, skin) of Nile tilapia (Oreochromis niloticus L.) fingerlings. Environ toxicol 21: 614-620.

28. Kaushal BT, Mishra A (2011) A comparative toxicity analysis of cadmium compounds on morphological and behavioral aspects in air breathing freshwater fish Channa punctatus. Int J Sci Nat 2: 266-269.

29. Vivek KG, Rajnish P, Nikhat JS, Sharma B (2015) Acetyl cholinesterase from Human Erythrocytes as a Surrogate Biomarker of Lead induced Neurotoxicity. Enzyme Res.

30. Annabi A, Messaoudi I, Kerkeni A, Said K (2011) Cadmium accumulation and histological lesion in mosquito fish (Gambusia affinis) tissues following acute and chronic exposure. Inter J Env Res 5: 745-756.

31. Favorito R, Chiarelli G, Grimaldi MC, De Bonis S, Lancieri M, et al. (2011) Bioaccumulation of cadmium and its cytotoxic effect on zebrafish brain. Chem Ecol 27: 39-46.

32. Xing H, Li S, Wang Z, Gao X, Xu S, et al. (2012) Histopathological changes and antioxidant response in brain and kidney of common carp exposed to atrazine and chlorpyrifos. Chemosphere 88: 377-383. 